\title{
Factors affecting adjustment to retirement among retirees' elderly persons
}

\author{
Doaa El Sayed Fadila*, Raefa Refaat Alam \\ Gerontological Nursing Department, Faculty of Nursing, Mansoura University, Egypt
}

Received: January 11, 2016

DOI: $10.5430 /$ jnep.v6n8p112
Accepted: March 8, 2016

Online Published: April 6, 2016

\begin{abstract}
Background and aim: The loss of work through retirement is one of the major adjustments for individual ages. For many, this is the first indicator of the impact of aging. Aim of the study was to identify factors affecting adjustment to retirement among retirees' elderly persons.

Method: Cross-sectional descriptive design was adopted. This study was conducted at Waiting Lounge of El Ahly Bank, Nasser Bank, and Faculties of Commerce, Medicine, Science and Veterinary affiliated to Mansoura University, Dakahlia Governorate, Egypt. 210 retirees' elderly person who represented the participants of the current study retired since one year and more. Data was collected using Self-Administered Questionnaire, Retirement Adjustment Scale, and Retirement Resources Inventory.

Results: None of the retirees' elderly $(100.0 \%)$ attended a preparation program for retirement. The total mean score of retirement adjustment scale correlated significantly and positively to the total mean score of the physical, financial, social, and mental resources. Additionally, there is a significant relation between preparation for retirement and the total mean score of retirement adjustment scale.

Conclusion: It can be concluded that adjustment to retirement was affected by the retirees' gender, marital status, level of education, type of job before retirement, job condition, and place of work. In addition, adequate resources as physical, financial, social support and mental capacity are associated with better adjustment to retirement.
\end{abstract}

Key Words: Retirement, Adjustment, Elderly, Retirees

\section{INTRODUCTION}

Growing old is not easy and involves various life changes which demand multiple adjustments requiring stamina, ability and flexibility. The loss of work through retirement is one of the major adjustments for individual ages. For many, this is the first indicator of the impact of aging. ${ }^{[1,2]}$

Retirement is defined as partial or complete withdrawal from career work accompanied by a change in the source and decrease of income. MacBean (2007) considered retirement as a process of gradually reducing labor force activity. ${ }^{[3]}$ The standard retirement age varies from country to country but it is generally between 55 to 70 years. In some countries, this age differs according to being males or females. The standard age of retirement in Egypt is considered 60 years with some exceptions where some employees retire at the age of 70 or a little bit earlier such as members of judiciary, university staff and researchers at the research centers. ${ }^{[4,5]}$

Retirement is not just a few years of rest from the hard work before death. It is a developmental stage that may represent 30 or more years of one's life and involves six phases:

\footnotetext{
*Correspondence: Doaa El Sayed Fadila; Email: doaa0377@yahoo.com; Address: Gerontological Nursing Department, Faculty of Nursing, Mansoura University, Egypt.
} 
preretirement (constituting of both the remote and the near phase), honeymoon phase, disenchantment phase, reorientation phase, stability phase, and termination phase. The preretirement phase occurs when the person meditates retirement and hypothesizes what it possibly results. The honeymoon phase is the process where the person feels enthusiastic about being in retirement and spends free time with fun activities. The disenchantment phase reflects distress at life slowing down, which can produce a feeling of depression. The reorientation phase involves adopting a more realistic view of possible alternatives within retirement. The stability phase is viewed as predicable and satisfying. The termination phase is a result of illness, disability, or loss of financial support; for example, one would be leaving the retirement role and leading the invalid role. ${ }^{[1,2,6]}$

Retirement is a significant life change that affects various areas. The transition from a life of work to one of retirement has both practical and emotional implications (e.g. living with lower income, having many leisure hours, having to leave a familiar and a well-known world). Responding to retirement occurs on an individual and a unique basis. Literature mentioned diverse responses to this basic life change with differences in intensity and style of response among retirees. ${ }^{[7-9]}$

Retirement should not be an obstacle in one's lifetime which hampers the retiree from being creative and capable of contributing to the society. Thus, having appropriate coping and adjustment skills in the transition to retirement could positively affect the results of this transition. ${ }^{[7]}$ Adjustment is known as the psychological processes through which people adapt or cope with the demands and challenges of everyday life. It is a person's ability to be familiar with his/her environment and situation. ${ }^{[10]}$ This reflects the changes an individual makes in his/her environment to enable him/her to live successfully in that environment. Consequently, adjustment should be considered as an inner process occurring at an individual and a social level to attain balance between the retiree and his/her interaction with the environment.

Adjustment to retirement is affected by the individual's flexibility as well as the society's readiness and the availability of other resources such as income, health, and social support system (friends, relatives, neighbors). ${ }^{[11]}$ In addition, other affecting factors include the level of control over the time of retirement; the importance of work for him/her; role as main caregiver for parents and/or spouse; marriage status (married or not); personality type and life style; the intergenerational relationship and how the retiree adapts with previous life transitions. ${ }^{[12]}$

The gerontological nurse can have a vital role in changing the life of the retirees into a better one through assessing the recourses needed for adjustment to retirement. This, in turn; will positively affect the design and development of pre-retirement planning programs that will enable workers to be prepared for their retirement in future and which may improve the retiree's conditions. ${ }^{[2]}$ Egyptian studies on retirement problems, challenges and adjustment of retirees and their experiences are rare. Accordingly, the aim of the present study was to identify factors affecting adjustment to retirement among retirees' elderly persons.

\section{Methods}

\subsection{Study design}

Cross-sectional descriptive study design was utilized in this study.

\subsection{Settings}

This study was carried out at Waiting Lounge of El Ahly Bank and Nasser Bank and Faculties of Commerce, Medicine, Science and Veterinary affiliated to Mansoura University, Dakahlia Governorate, Egypt.

\subsection{Subjects}

Sample size was calculated online. The pilot study revealed that the mean $=38.3$ and $\mathrm{SD}=14.9$. With alpha error $=5 \%$, study power $90 \%$ and the effect size of 3 , then the expected sample size was 209 at least. The study subjects included 210 retirees aged 60 years and above, retired since 1 year and more, able to communicate and accept to participate in the study.

\subsection{Tools}

Self administered questionnaire was developed by the researchers based on review of relevant literature $;^{[1,2,12]}$ it includes: Socio demographic data as: age, gender, marital status, level of education, etc. Job characteristics as: type of job, job experience, duration since retirement, job condition, place of work and preparation for retirement.

Retirement Adjustment Scale was developed by Wells et al., 2006 ${ }^{[13]}$ to assess the elderly person's adjustment to retirement. It consists of 13 statements. The scale is a 5-point likert scale with response options for strongly agree takes a score of 5, agree 4, mixed feeling 3 , disagree 2, and strongly disagree 1 . The statements from 4 to 11 are reversibly scored (i.e. a score of " 5 " is re-coded as a " 1 ", a score of " 1 " is recoded as a "5" and vice versa). Statement 13 if participants are not married or partnered, the average scores of statements from 1 to 12 is used instead. A total score of adjustment of retiree is calculated of each study retiree by summing upgrading ratings across the 13 statements with 
possible scores ranging from 13 to 65 . Higher scores indicate better adjustment to retirement.

Retirement Resources Inventory was developed by Leung and Earl 2012 ${ }^{[14]}$ to assess resources relevant to retirement wellbeing. The inventory consists of 35 items. It encompasses three resource domains namely: physical and financial resources, social resources and mental capacity "emotional, cognitive and motivational". The scale is a 5- point likert scale with appropriate anchors is used. Items 2, 3, 22, 24, 34 and 35 are reversibly scored (a score of 1 is reversed to a 5 , a score of 2 is reversed to a 4 , and so on). A total score of inventory is calculated of each study retiree by summing upgrading ratings across the 35 items with possible scores ranging from 35 to 175 . Calculate subscale scores by summing up item ratings (physical and financial domain is scored between 8 to 40, social domain is scored between 9 to 45 and mental domain is scored between 18 to 90 ). Higher scores indicate better resources to retirement.

\subsection{Procedure}

Retirement adjustment scale and retirement resources inventory were translated into Arabic by researchers and tested for content validity by a jury of 7 experts then they were tested for reliability by test-retest method. The reliability was assured by means of Cronbach's coefficient alpha. Retirement adjustment scale has a reliability of 0.91 and retirement resources inventory 0.88 . A pilot study was carried out on $10 \%$ of the study sample to evaluate the ambiguity, clarity and applicability of the tools. Accordingly, the necessary modifications were done.

An official letter was issued from the Faculty of Nursing, Mansoura University and forwarded to the manager of each bank and Dean of each faculty separately in order to obtain their approval to carry out the study. After establishing a trustful relationship, each subject was interviewed by the researchers to explain the study purpose then study tools were completed by retirees. The data was collected for a period of one year from the first of June 2014 till the end of May 2015.

\subsection{Ethical considerations}

A verbal consent from the retirees to participate in the study was obtained after explanation of the study purpose. Privacy, confidentiality, anonymity and the right to withdraw at any time was assured.

\subsection{Statistical analysis}

The Statistical Package for Social Sciences "SPSS" software version 20.0 was utilized. The 0.05 level was used as the cut off value for statistical significance. Descriptive statistics: Count and percentage were used for describing and sum- marizing qualitative data. Arithmetic mean (X), Standard deviation (SD) were used as measures of central tendency and dispersion respectively for normally distributed quantitative data. Minimum-maximum and median were used for presented non parametric quantitative data. Analytical statistics include: Independent sample $t$-test and $F$-test (One Way ANOVA).

Table 1. Socio-demographic and job characteristics of retirees' elderly

\begin{tabular}{|c|c|c|}
\hline Items & $N=210$ & $\%$ \\
\hline \multicolumn{3}{|l|}{ Age (in years) } \\
\hline $60-65$ & 110 & 52.4 \\
\hline $65-70$ & 65 & 31.0 \\
\hline $70+$ & 35 & 16.6 \\
\hline Mean \pm SD & $64.91 \pm 3.51$ & \\
\hline \multicolumn{3}{|l|}{ Gender } \\
\hline Male & 120 & 57.1 \\
\hline Female & 90 & 42.9 \\
\hline \multicolumn{3}{|l|}{ Marital status } \\
\hline Single & 5 & 2.4 \\
\hline Married & 130 & 61.9 \\
\hline Divorced & 10 & 4.7 \\
\hline Widow & 65 & 31.0 \\
\hline \multicolumn{3}{|l|}{ Educational level } \\
\hline Read and write & 20 & 9.5 \\
\hline Primary education & 25 & 11.9 \\
\hline Secondary education & 30 & 14.3 \\
\hline University education & 70 & 33.3 \\
\hline Post graduation & 65 & 31.0 \\
\hline \multicolumn{3}{|l|}{ Current work } \\
\hline Yes & 55 & 26.2 \\
\hline No & 155 & 73.8 \\
\hline \multicolumn{3}{|l|}{ Type of job } \\
\hline Employee & 90 & 42.9 \\
\hline Teacher & 55 & 26.2 \\
\hline Worker & 35 & 16.7 \\
\hline Business man & 15 & 7.1 \\
\hline Engineer & 10 & 4.7 \\
\hline Faculty Member & 5 & 2.4 \\
\hline \multicolumn{3}{|l|}{ Job experience } \\
\hline$<20$ & 15 & 7.1 \\
\hline$\geq 20$ & 195 & 92.9 \\
\hline Mean \pm SD & $28.38 \pm 5.95$ & \\
\hline \multicolumn{3}{|l|}{$\begin{array}{l}\text { Duration since } \\
\text { retirement (years) }\end{array}$} \\
\hline$<5$ & 110 & 52.4 \\
\hline $5-10$ & 65 & 31.0 \\
\hline$>10$ & 35 & 16.6 \\
\hline Mean \pm SD & $5.05 \pm 3.54$ & \\
\hline \multicolumn{3}{|l|}{ Job condition } \\
\hline Permanent & 150 & 71.4 \\
\hline Temporary & 60 & 28.6 \\
\hline \multicolumn{3}{|l|}{ Place of work } \\
\hline Governmental & 140 & 66.7 \\
\hline Private & 70 & 33.3 \\
\hline
\end{tabular}


Table 2. Preparation for retirement

\begin{tabular}{lll}
\hline Items & $\mathbf{N}=\mathbf{2 1 0}$ & $\mathbf{\%}$ \\
\hline Attending program before retirement & & \\
-No & 210 & 100.0 \\
Discussing retirement plans with others & & \\
-Never & 65 & 31.0 \\
-Rarely & 90 & 42.8 \\
-Sometimes & 55 & 26.2 \\
Read or heard about retirement & & \\
-Never & 115 & 54.8 \\
-Rarely & 95 & 45.2 \\
Planning for financial status & & \\
-Never & 15 & 7.1 \\
-Rarely & 90 & 42.9 \\
-Sometimes & 60 & 28.6 \\
-Often & 45 & 21.4 \\
Planning for leisure time & & 35.6 \\
-Never & 75 & 31.0 \\
-Rarely & 65 & 31.0 \\
-Sometimes & 65 & 2.4 \\
-Often & 5 & \\
\hline
\end{tabular}

\section{RESULTS}

As shown in Table 1, the mean age of the retirees' elderly was $64.91 \pm 3.51$ years. As for gender, males constituted
$57.1 \%$ of the retirees' elderly. Nearly two thirds $(61.9 \%)$ were married, while $31.0 \%$ of them were widowed. With regard to the educational level, $33.3 \%$ of the retirees' elderly were university graduate and $31.0 \%$ had a post-graduation degree. Only $9.5 \%$ could just read and write. $73.8 \%$ of the retirees don't have a current work.

The study results reveal that, $42.9 \%$ and $26.2 \%$ of the retirees were employees and teachers respectively. Those who were workers constituted $16.7 \%$ of the retirees' elderly. Regarding to the job experience, $92.9 \%$ of retirees' elderly had worked for 20 years or more. Concerning duration since retirement, it is noticed that, more than half of the sample (52.4\%) retired since 1 to less than 5 years, while $(31.0 \%)$ of them retired since 5 to less than 10 years and the rest $(16.7 \%)$ retired since 10 years or more. The mean duration since retirement was $5.05 \pm 3.54$ years. As for job condition, $71.4 \%$ were permanent workers in their previous job with only $28.6 \%$ were temporal workers. As for place of work, two thirds $(66.7 \%)$ have worked in governmental places while $33.3 \%$ in private places.

Table 3. Retirement adjustment of retirees' elderly

\begin{tabular}{|c|c|c|c|c|c|c|c|c|c|c|c|}
\hline \multirow{2}{*}{$\begin{array}{l}\text { Retirement adjustment } \\
\text { items }\end{array}$} & \multicolumn{2}{|c|}{$\begin{array}{l}\text { Strongly } \\
\text { disagree }\end{array}$} & \multicolumn{2}{|c|}{ Disagree } & \multicolumn{2}{|c|}{ Neutral } & \multicolumn{2}{|c|}{ Agree } & \multicolumn{2}{|c|}{ Strongly agree } & \multirow[t]{2}{*}{ Mean \pm SD } \\
\hline & No & $\%$ & No & $\%$ & No & $\%$ & No & $\%$ & No & $\%$ & \\
\hline $\begin{array}{l}\text { I will adjusted to the } \\
\text { changes }\end{array}$ & 0 & 0.0 & 75 & 35.7 & 45 & 21.4 & 80 & 38.1 & 10 & 4.8 & $3.12 \pm 0.96$ \\
\hline I enjoy being retired & 10 & 4.8 & 85 & 40.5 & 45 & 21.4 & 60 & 28.6 & 10 & 4.8 & $2.88 \pm 1.03$ \\
\hline I am busy & 10 & 4.8 & 85 & 40.5 & 65 & 31.0 & 50 & 23.8 & 0 & 0.0 & $2.74 \pm 0.88$ \\
\hline $\begin{array}{l}\text { I have real concern about } \\
\text { my financial situation }\end{array}$ & 30 & 14.3 & 50 & 23.8 & 35 & 16.7 & 80 & 38.1 & 15 & 7.1 & $3.00 \pm 1.22$ \\
\hline $\begin{array}{l}\text { I miss the stimulation that } \\
\text { work gave me }\end{array}$ & 45 & 21.4 & 45 & 21.4 & 25 & 11.9 & 60 & 28.6 & 35 & 16.7 & $3.02 \pm 1.43$ \\
\hline $\begin{array}{l}\text { I wish I had started to plan } \\
\text { for retirement earlier }\end{array}$ & 25 & 11.9 & 45 & 21.4 & 40 & 19.0 & 80 & 38.1 & 20 & 9.5 & $3.12 \pm 1.20$ \\
\hline $\begin{array}{l}\text { I miss the discipline that } \\
\text { working gave me }\end{array}$ & 25 & 11.9 & 75 & 35.7 & 25 & 11.9 & 65 & 31.0 & 20 & 9.5 & $3.10 \pm 1.23$ \\
\hline $\begin{array}{l}\text { People don't respect me as } \\
\text { much now that I am retired }\end{array}$ & 40 & 19.0 & 60 & 28.6 & 35 & 16.7 & 75 & 35.7 & 0 & 0.0 & $3.31 \pm 1.15$ \\
\hline $\begin{array}{l}\text { I have had to adjust to a big } \\
\text { drop in my income }\end{array}$ & 25 & 11.9 & 65 & 31.0 & 50 & 23.8 & 60 & 28.6 & 10 & 4.8 & $3.17 \pm 1.11$ \\
\hline $\begin{array}{l}\text { I miss being part of the } \\
\text { action }\end{array}$ & 30 & 14.3 & 60 & 28.6 & 55 & 26.2 & 60 & 28.6 & 5 & 2.4 & $3.24 \pm 1.09$ \\
\hline $\begin{array}{l}\text { Retirement has not lived up } \\
\text { to my expectation }\end{array}$ & 5 & 2.4 & 80 & 38.1 & 25 & 11.9 & 80 & 38.1 & 20 & 9.5 & $2.86 \pm 1.11$ \\
\hline $\begin{array}{l}\text { Retirement has been better } \\
\text { than I expected }\end{array}$ & 20 & 9.5 & 60 & 28.6 & 75 & 35.7 & 45 & 21.4 & 10 & 4.8 & $2.83 \pm 1.02$ \\
\hline $\begin{array}{l}\text { If married or partnered I } \\
\text { enjoy being able to spend } \\
\text { more time with my } \\
\text { spouse/partner }\end{array}$ & 70 & 33.3 & 20 & 9.5 & 40 & 19.0 & 40 & 19.0 & 40 & 19.0 & $2.81 \pm 1.53$ \\
\hline Total mean score & 39.1 & 13.53 & & & & & & & & & \\
\hline
\end{tabular}


It is evident from Table 2 that, none of the retirees' elderly (100.0\%) attended a preparation program for retirement. $31 \%$ and $42.9 \%$ of retirees never and rarely discussed retirement plans with others respectively. $54.8 \%$ of retirees followed by $45.2 \%$ of them reported that they never and rarely read or heard about retirement. Concerning planning for financial status, only $21.4 \%$ of retirees often planned for financial status while $42.9 \%$ were rarely. As for planning for leisure time, $35.7 \%$ of retirees never planned their leisure activities.

As observed from Table 3, the statement that denotes (people don't respect me as much now that I am retired), had the higher mean score $(\mathrm{X} \pm \mathrm{SD}=3.31 \pm 1.15)$ and was agreed by (35.7\%) of the elderly followed by (I miss being part of the action) $(\mathrm{X} \pm \mathrm{SD}=3.24 \pm 1.09)$ and $(28.6 \%)$ were agreed with it. The statements that denote (I have had to adjust to a big drop in my income) and (I will adjusted to the changes) had mean scores of $(\mathrm{X} \pm \mathrm{SD}=3.17 \pm 1.11,3.12 \pm 0.96$ respectively), and (28.6\%, $38.1 \%$ respectively) were agree with them.

Table 4 reveals that, total mean score of retirement adjustment scale correlated significantly and positively to the total mean score of the three resources (physical and financial resources, social resources, and mental capacity) when applying the retirement resources inventory.

Table 4. Correlation between retirement resources inventory of retirees' elderly and their total mean score of retirement adjustment scale

\begin{tabular}{llll}
\hline $\begin{array}{l}\text { Retirement } \\
\text { resources } \\
\text { inventory items }\end{array}$ & \multicolumn{2}{l}{$\begin{array}{l}\text { Total mean score of retirement } \\
\text { adjustment scale }\end{array}$} & $\begin{array}{l}\text { Test of } \\
\text { significance }\end{array}$ \\
\cline { 2 - 3 } & Mean \pm SD & (Min-Max) & \\
\hline $\begin{array}{l}\text { Physical and } \\
\text { financial resources }\end{array}$ & $26.10 \pm 5.66$ & $3-18$ & $0.936(0.000)^{*}$ \\
$\begin{array}{l}\text { Social resources } \\
\text { Mental capacity }\end{array}$ & $27.52 \pm 6.46$ & $4-16$ & $0.908(0.000)^{*}$ \\
Total mean score & $110.17 \pm 23.84$ & $78-153$ & $0.947(0.000)^{*}$ \\
\hline
\end{tabular}

* Correlation is significant at the 0.01 level (2-tailed).

Table 5 presents that no statistical significant difference between age groups and total mean score of retirement adjustment scale $[F=0.056, P=.945]$.

Concerning gender, it was observed that male had a higher mean score than female in adjustment to retirement $(\mathrm{X}=$ $41.25 \pm 12.40$ for male, $X=36.44 \pm 14.53$ for female). A statistical significant difference was observed between adjustment to retirement and gender [T $=2.523, P=.013]$.

As regards marital status, married obtained a higher mean score of adjustment to retirement $(X=44.85 \pm 12.60)$ whereas, single had a lower mean score $(X=28.00 \pm 0.00)$. Significant difference between marital status and adjustment to retirement was found [ $F=28.243, P=.000]$.

Table 5. Relation between socio-demographic characteristics of retirees' elderly and their total mean score of retirement adjustment scale

\begin{tabular}{|c|c|c|}
\hline \multirow{2}{*}{$\begin{array}{l}\text { Socio-demographic } \\
\text { characteristics items }\end{array}$} & $\begin{array}{l}\text { Total mean score of retire- } \\
\text { ment adjustment scale }\end{array}$ & \multirow{2}{*}{$\begin{array}{l}\text { Test of } \\
\text { significance }\end{array}$} \\
\hline & Mean \pm SD & \\
\hline \multicolumn{3}{|l|}{ Age (in years) } \\
\hline $60-$ & $38.91 \pm 13.55$ & \multirow{3}{*}{$\begin{array}{l}F=0.056 \\
P=0.945\end{array}$} \\
\hline $65-$ & $39.62 \pm 13.63$ & \\
\hline $70+$ & $39.29 \pm 13.66$ & \\
\hline \multicolumn{3}{|l|}{ Gender } \\
\hline Male & $41.25 \pm 12.40$ & \multirow{2}{*}{$\begin{array}{l}\mathrm{T}=2.523 \\
P=0.013^{*}\end{array}$} \\
\hline female & $36.44 \pm 14.53$ & \\
\hline \multicolumn{3}{|l|}{ Marital status } \\
\hline Single & $28.00 \pm 0.00$ & \multirow{4}{*}{$\begin{array}{l}F=28.243 \\
P=0.000 *\end{array}$} \\
\hline Married & $44.85 \pm 12.60$ & \\
\hline Divorced & $34.50 \pm 19.50$ & \\
\hline Widow & $29.46 \pm 7.10$ & \\
\hline \multicolumn{3}{|l|}{ Educational level } \\
\hline Read and write & $30.00 \pm 1.62$ & \multirow{5}{*}{$\begin{array}{l}F=65.476 \\
P=0.000^{*}\end{array}$} \\
\hline Primary education & $25.40 \pm 5.23$ & \\
\hline Secondary education & $26.00 \pm 3.81$ & \\
\hline University education & $41.14 \pm 12.99$ & \\
\hline Post graduation & $51.31 \pm 7.95$ & \\
\hline \multicolumn{3}{|l|}{ Current work } \\
\hline Yes & $38.09 \pm 10.48$ & \multirow{2}{*}{$\begin{array}{l}\mathrm{T}=0.814 \\
P=0.417\end{array}$} \\
\hline No & $39.58 \pm 14.47$ & \\
\hline
\end{tabular}

${ }^{*}$ Significant $P \leq .05 ; F=$ One way ANOVAs test; T $=$ student $t$-test

Regarding level of education, the table shows that postgraduation retirees' had a higher mean score in adjustment to retirement $(X=51.31 \pm 7.95)$ followed by university education $(X=41.14 \pm 12.99)$. Statistical significant difference was observed between level of education and adjustment to retirement $[F=65.476, P=.000]$.

Concerning current work, no statistical significant difference was found between current work and total mean score of retirement adjustment scale [T $=0.814, P=.417]$.

Table 6 shows that, a statistically significant difference between the total mean score of retirement adjustment scale and type of job before retirement $[F=33.714, P=.000]$. As for job experience, the difference was statistically significant between the total mean score of retirement adjustment scale and job experience $[\mathrm{T}=2.052, P=.041]$.

Regarding job condition, the retirees' who have permanent job had a higher mean score in adjustment to retirement ( $\mathrm{X}$ $=43.93 \pm 13.02)$ compared to those who had temporal job condition $(X=27.33 \pm 4.57)$. Significant difference between job and adjustment to retirement was found $[\mathrm{T}=13.656, P$ $=.000]$. 
Table 6. Relation between job characteristics of retirees' elderly and their total mean score of retirement adjustment scale

\begin{tabular}{lll}
\hline $\begin{array}{l}\text { Job characteristics } \\
\text { items }\end{array}$ & $\begin{array}{l}\text { Total mean score of } \\
\text { retirement adjustment scale }\end{array}$ & $\begin{array}{l}\text { Test of } \\
\text { significance }\end{array}$ \\
\cline { 2 - 2 } Type of job & Mean \pm SD & \\
Faculty Member & $54.00 \pm 0.00$ & \\
Engineer & $53.43 \pm 10.51$ & \\
Employee & $51.00 \pm 1.05$ & \\
Teacher & $44.33 \pm 14.18$ & $F=33.714$, \\
Business man & $37.61 \pm 12.40$ & $P=(.000)^{*}$ \\
Worker & $27.82 \pm 3.57$ & \\
Job experience & & $\mathrm{T}=2.052$, \\
(year) & & $P=(.041)^{*}$ \\
$<20$ & $32.33 \pm 11.54$ & \\
$>20$ & $39.72 \pm 13.56$ & \\
Duration since & & $F=0.128$, \\
retirement (years) & & $P=(.880)$ \\
$<5$ & $38.77 \pm 13.77$ & $\mathrm{~T}=13.656$, \\
5-10 & $39.85 \pm 13.37$ & $P=(.000)^{*}$ \\
$>10$ & $39.29 \pm 13.66$ & \\
Job condition & & $\mathrm{T}=15.315$, \\
Permanent & $43.93 \pm 13.02$ & $P=(.000)^{*}$ \\
\hline Temporary & $27.33 \pm 4.57$ & \\
Place of work & & \\
Governmental & $45.21 \pm 12.50$ & \\
Private & $27.14 \pm 4.40$ & \\
\hline
\end{tabular}

* Significant $P \leq .05 ; \mathrm{F}=$ One way ANOVAs test; $\mathrm{T}=$ student $t$-test

Concerning place of work, retirees' engaged in governmental work had a higher mean score $(X=45.21 \pm 12.50)$. Whereas, those with private work had a lower mean score $(X=27.14$ \pm 4.40 ). The difference was statistically significant between the total mean score of retirement adjustment scale and place of work before retirement [T $=15.315, P=.000]$. No significant difference was found between duration since retirement and the total mean score of retirement adjustment scale [ $F=$ $0.128, P=.880]$.

It appears from the Table 7 that, the differences between preparation for retirement items (discussing retirement plans with others, read or heard about retirement, planning for financial status, and planning for leisure time) and the total mean score of retirement scale were statistically significant $[P=.000]$.

\section{Discussion}

Traditionally, retirement has been viewed as the gateway to old age. Work is more than earning a living. It is a way to live. Retirement is not only an occupational career transition, but a family transition as well. ${ }^{[15]}$ Retiring from the workforce can represent a significant change for many individuals. Changes can be felt on a financial, social and emotional level and can influence new retirees' standard of living, daily activities, social networks and well-being. Although there has been extensive research on retirement adjustment, results have been inconsistent and thus remain inconclusive regarding the nature of the impact of retirement. On the one hand, retirement has been found to have beneficial effects. While, on the other hand, some studies suggest that retirement has important negative effects. Thus, a better understanding of adjustment process would provide a clearer picture of the outcomes, that is, the challenges and costs that it generates at the individual and societal level. ${ }^{[16-18]}$ Therefore, the aim of the present study was to identify factors affecting adjustment to retirement among retirees' elderly.

Table 7. Relation between preparation for retirement of retirees' elderly and their total mean score of retirement adjustment scale

\begin{tabular}{|c|c|c|}
\hline \multirow{2}{*}{$\begin{array}{l}\text { Preparation for } \\
\text { retirement items }\end{array}$} & $\begin{array}{l}\text { Total mean score of } \\
\text { retirement adjustment scale }\end{array}$ & \multirow[t]{2}{*}{$\begin{array}{l}\text { Test of } \\
\text { significance }\end{array}$} \\
\hline & Mean \pm SD & \\
\hline \multicolumn{3}{|c|}{$\begin{array}{l}\text { Discuss retirement } \\
\text { plans with others }\end{array}$} \\
\hline Never & $27.23 \pm 4.40$ & \multirow{3}{*}{$\begin{array}{l}F=94.405 \\
P=.000^{*}\end{array}$} \\
\hline Rarely & $40.06 \pm 13.99$ & \\
\hline Sometimes & $51.91 \pm 5.03$ & \\
\hline \multicolumn{3}{|c|}{$\begin{array}{l}\text { Read or heard about } \\
\text { retirement }\end{array}$} \\
\hline Never & $29.39 \pm 7.70$ & \multirow{2}{*}{$\begin{array}{l}F=366.010 \\
P=.000^{*}\end{array}$} \\
\hline Rarely & $51.05 \pm 8.70$ & \\
\hline \multicolumn{3}{|l|}{$\begin{array}{l}\text { Planning for } \\
\text { financial status }\end{array}$} \\
\hline Never & $25.00 \pm 0.85$ & \multirow{4}{*}{$\begin{array}{l}F=152.041 \\
P=.000^{*}\end{array}$} \\
\hline Rarely & $28.94 \pm 7.36$ & \\
\hline Sometimes & $46.58 \pm 10.88$ & \\
\hline Often & $54.56 \pm 1.44$ & \\
\hline \multicolumn{3}{|c|}{$\begin{array}{l}\text { Planning for leisure } \\
\text { time }\end{array}$} \\
\hline Never & $26.53 \pm 4.19$ & \multirow{4}{*}{$\begin{array}{l}F=123.662 \\
P=.000^{*}\end{array}$} \\
\hline Rarely & $39.38 \pm 13.07$ & \\
\hline Sometimes & $52.31 \pm 4.75$ & \\
\hline Often & $56.00 \pm 0.00$ & \\
\hline
\end{tabular}

$* p<.05$.

The transition to retirement is unique to each individual and is influenced by many factors i.e. retirees' attributes and environmental features. Such factors include socio-demographics (age, gender, education level and socioeconomic status), psychosocial factors (marital status and social support) and contextual factors (perceived health, control and planning and retirement decision). ${ }^{[16-18]}$

\subsection{Sociodemographic characteristics}

In relation to gender, the present study findings proved that there was a significant relation between gender and adjust- 
ment to retirement. Older males had a higher mean score in adjustment to retirement than older females (see Table 5). This may be explained by the differences in socialization processes, cultural expectations and social roles between women and men that play a role in explaining gender differences in the ways in which women and men adjust to stress. Males and females also differ in their spending and savings patterns. There is evidence that females have more negative attitudes towards retirement than males do, and that retirement is more disruptive and more likely to be linked with greater loneliness and depression for females than for males. ${ }^{[19]}$ Males and females behave differently in many respects. Whereas males in general are risk takers, most females are risk averse. ${ }^{[20]}$ In line with these results Van Solinge \& Henkens (2005) added that females tend to have greater problems adjusting to retirement, both as retirees and as partners. ${ }^{[21]}$ Men tend to be more satisfied with retirement than are women and female retirees more often report distress. ${ }^{[22]}$ Smith \& Moen (2004) in USA reported the same results. ${ }^{[23]}$

Concerning marital status, the study revealed that being married was associated with better adjustment to retirement (see Table 5). This may be related to the support given by spouses, which might help to decrease the stress responses and to adjust effectively. ${ }^{[24]}$ Previous research suggests that marriage and family relationships serve as social relational resources in retirement adjustment. Being married and having a high quality marriage contributes to post-retirement well-being, whereas marital problems enhance perceptions of retirement related hassles. ${ }^{[19,25]}$ This is in accordance with Price \& Joo (2005) and Bierman et al. (2006) in USA who reported that marital status has been correlated with retirement adjustment, such that married persons tend to report better mental health outcomes and happiness than non-married persons. ${ }^{[26,27]}$

Education is the cornerstone for better adjustment. Education helps the individual's view stressful life events without overestimating or over valuing the situation. Increased level of education makes the individuals more knowledgeable, more mature in their behaviors and able to accept facts. People acquire a sense of control over events when they have information that makes them form a mental image of these events. ${ }^{[28]}$ Moreover, lower educational level lead to increase the spare time the elderly spend with no valuable activity as illiteracy decreases the chance to spend time in reading or being creative in another area. ${ }^{[29]}$ This is in agreement with the result of the present study where retirees' elderly with high education level had a higher mean score in adjustment to retirement (see Table 5). On the same line, Lusardi \& Mitchell (2003) in USA added that, less educated people are most likely not to think about retirement and be less likely to have basic financial knowledge. ${ }^{[30]}$ A study conducted by Asamoah (2012) in Ghana reported that the educational background of respondents is likely to influence a respondents' adjustment and preparation towards retirement. The higher the educational level the better the job prospects and the higher the income and probably higher savings habit. ${ }^{[31]}$

\subsection{Physical resources}

Furthermore, elders' economic status can be another variable that influence elder's ability to adjust effectively. Monetary resources expand coping options in nearly all stressful situations, providing easier and probably more effective access to legal, medical and other professional assistance. Even when money is not spent directly on managing the problem, financial security can reduce the impact of stress. ${ }^{[32]}$ Also, good health may facilitate retirement plans and in turn increase retirement satisfaction. Poor health in retirement may disrupt the plans elderly had for this stage of their lives. Elders' health problems may affect satisfaction with retirement, since health problems of one of the partners restrict the possibility of taking up new activities for both partners. ${ }^{[33]}$ This is in accordance with the present study findings which proved that there was a statistically significant relation between physical resources (health and income) and adjustment to retirement (see Table 4). In the same context, studies done by Kim \& Moen (2002) and Szinovacz \& Davey (2004) in USA have found that inadequate incomes and financial problems predict dissatisfaction and maladjustment to retirement. ${ }^{[19,25]}$ In contrast Van Solinge \& Henkens (2005) in The Netherlands have concluded that health and finances have no significant effect on adjustment to retirement. ${ }^{[21]}$

\subsection{Social resources}

Retirement requires a reorganization of activities and leisure time. Participation in activities contributes to retirement adaptation, whereas boredom is related to difficult adjustment. ${ }^{[19,33,34]}$ In this respect, the present study revealed that social resources are associated positively and significantly with adjustment to retirement (see Table 4). Taylor et al. (2008) in USA studied the effects of retirement expectations and social support on adjustment and concluded that social sources, quality of social interactions and the type of social support significantly predicted retirement satisfaction among retirees 10 months after retirement. ${ }^{[35]}$ Kim \& Moen (2001) added that the presence of marriage, family, friendship networks and group affiliations all play a role in enhancing retirement well-being. ${ }^{[33]}$

\subsection{Mental capacity resources}

The regulation of subjective wellbeing occurs through mental capacity that promotes adaptation to adverse situations. Many life events are out of control and wellbeing is derived 
from how one faces up to and deals with such situations. Well-being or satisfaction with retirement is thus partly dependent on how older workers face up to and deal with the transition. ${ }^{[36]}$ This is in accordance with the result of the present study where a statistically significant relation between mental capacity and adjustment to retirement was found (see Table 4). Positive emotions and emotional intelligence emerged as two significant emotional resources that could potentially benefit retirement well-being. Recently, Lockenhoff, Terracciano and Costa (2009) in USA reported a positive correlation between retirement satisfaction and the positive emotions. ${ }^{[37]}$ A second key emotional resource, emotional intelligence, is defined as the ability to perceive, generate, understand and manage emotions. ${ }^{[38]}$ In a series of two studies, Slaski and Cartwright $(2002,2003)$ in UK found that emotional intelligence was associated with less perceived stress and greater well-being; and the relationship between emotional intelligence and wellbeing was causal such that emotional intelligence training boosted both emotional intelligence and well-being. ${ }^{[39,40]}$

Additionally, Cognitive resources and abilities vital for successful aging include memory, processing speed, problem solving skills and learning ability. Cognitive resources underlie the processes that promote a sense of control, coping and adaptation. ${ }^{[41,42]}$ Previous studies reported that cognitive functioning predicted successful aging, positive affect and adaptation in older adults. ${ }^{[41,43]}$ Self-esteem, mastery and optimism were previously shown to predict various indices of retirement well-being. ${ }^{[4,45]}$ Evidence from a range of studies suggests that psychological resources have significant influences on retirement adjustment. ${ }^{[17,33]}$

\subsection{Job characteristics}

Individuals strive for social status. Status is largely determined by occupational prestige. After retirement, status will become difficult to maintain because status through occupational prestige is reduced. ${ }^{[46]}$ The present study portrays that the difference was statistically significant between type of job before retirement and the total mean score of retirement adjustment scale and those who worked in high status job had low mean score of adjustment to retirement (see Table 6). In the same direction, a study carried out in The Netherlands by van Solinge and Henkens (2008) showed that retiring from an occupation that is not challenging, absorbs many hours a week, and is of low status or demanding it does not increase the individual's satisfaction with retirement. ${ }^{[47]}$ Additionally, another study conducted by Schmidt \& Lee (2008) in Canada added that people with higher work status are more committed to their work role, they may experience greater difficulty adjusting to retirement than those with lower work

Published by Sciedu Press status. ${ }^{[48]}$

The current study showed a statistically significant difference between the total mean score of retirement adjustment scale and job experience and those who had job experience more than 20 years, had higher mean score of adjustment to retirement (see Table 6). In the same direction, Asamoah (2012) in Ghana stated that, the length of time a respondent has worked and his/her position at work place may give an indication of his or her savings level, and his/her preparedness to retire. Those who have worked for many years are nearing their retirement age and thus they are expected to be better prepared for retirement than newly recruited workers. ${ }^{[31]}$ Van Solinge and Henkens (2005) in The Netherlands added that adjustment to retirement is influenced by the context in which the transition is made as well as individual psychological factors. A strong "quantitative" attachment to work (full-time jobs, long work histories), a lack of control over the transition, retirement anxiety (negative preretirement expectations), and low scores on self-efficacy are predictors of difficult adjustment. ${ }^{[21]}$

Concerning duration since retirement, the result of current study revealed no significant difference between duration since retirement and the total mean score of retirement adjustment scale. This is in agreement with a study conducted by Wong and Earl (2009) in Australia who reported that retirees who were retired for more years did not tend to report better retirement adjustment. ${ }^{[49]}$ According to Atchley's (1976) process model of retirement adjustment, the initial elevation in retirees' wellbeing and adjustment immediately after retirement is short-lived; retirement adjustment drops once retirees adopt a more realistic view of retirement and later stabilizes once retirees accommodate to their new life. ${ }^{[35]}$

Permanent workers behave differently from their temporary workers. This is because the permanent workers have stable job and income. As a result their expenditure and saving profiles could be well managed. The present study findings proved that there was a statistically significant relation between job condition and adjustment to retirement (see Table 6 ). The same findings were reported in the study done in Ghana by Asamoah (2012). ${ }^{[31]}$

The present study revealed that the difference was statistically significant between the total mean score of retirement adjustment scale and place of work before retirement. Retirees' elderly in governmental jobs had a higher mean score in adjustment to retirement, whereas those in private jobs had a lower mean score. This may be explained by the fact that, economic resources for retirees as retirement pension and health insurance are better covered by governmental sectors 
than private-one.

\subsection{Preparation for retirement}

Hershey et al. (2003) considered several retirement adjustment measures including collecting information about retirement, seeking advice and relevant information, discussing retirement plans with others, and establishing how much money will be needed in retirement. ${ }^{[50]}$ Clarke-Murphy and Gerrans (2001) in Australia considered the collection and use of information, the use of seminars, as well as the consultation with others when making decisions regarding financial preparation. ${ }^{[51]}$ In this regard, the current study revealed that all participants did not attend preretirement preparation programs and rarely discussed retirement with others (see Table 2). There are many reasons why people do not prepare adequately for retirement. Retiree' are not able to come to terms with the realities of retirement and thus are bound to face hardships during and even after retirement. Some may simply deny the problem or overestimating the value of their future pension benefits and, as a result, has an overly optimistic view of their lifestyle in retirement. ${ }^{[52]}$ Fore (2003) finds a significant lack of financial knowledge among employees, and Lusardi (2003) suggests that some people are poorly informed because for them gaining information is too costly. ${ }^{[30,53]}$

In addition, adequate preparation to retirement is essential for better adjustment. Planning for retirement has been associated with lower anxiety, better adjustment and higher satisfaction than not planning. ${ }^{[54]}$ If effective, retirement planning should enhance an individual's sense of preparedness for the retirement event and make for an easier retirement decision if it reduces any anticipatory anxiety associated with the retirement event. In this respect, the present study revealed that there is a significant relation between preparation for retirement of retirees' elderly and their total mean score of retirement adjustment scale where those who did not discuss retirement plans with others, read or heard about retirement, planning for financial status, and planning for leisure time had lower mean score of adjustment to retirement than those who did (see Table 7). These findings are somewhat similar to another research by Joo \& Pauwels (2002) who found a positive relationship between preparation for retirement and adjustment toward retirement. ${ }^{[5]}$ Further, this could be related to findings that realistic expectations and clear financial goals lead to specific planning activities for retirement. ${ }^{[56]}$
Calculating retirement funds allows individuals to realize how much they need to save for their comfortable retirement. In the same context, a study done by Wong and Earl (2009) in Australia confirmed that preparedness for retirement and an easier retirement decision both predicted better retirement adjustment. ${ }^{[49]}$ These results build on the extent literature and lend support to the suggestion that the conditions by which retiring individuals exit their organization deserve attention in career transition and retirement discussions. ${ }^{[57]}$ Furthermore, the results add weight to Matour and Prout's (2007) recommendation that workers be encouraged to plan early for their retirement. ${ }^{[57]}$ Noone et al. (2009) in New Zealand indicated that those who had discussed retirement with their spouses and had retirement saving plans reported greater well-being. ${ }^{[58]}$

\section{Conclusion}

Based on the present study findings, it can be concluded that adjustment to retirement was affected by the retirees' gender, marital status, level of education, type of job before retirement, job condition, and place of work. In addition, adequate resources as physical, financial, social support and mental capacity are associated with better adjustment to retirement. Additionally, there is a significant relation between preparation for retirement and total mean score of retirement adjustment scale.

\section{RECOMMENDATION}

(1) Further studies address impact of pre-retirement planning program on physical and psychosocial wellbeing of retirees' elderly.

(2) Further studies involving a large number of retirees' are needed to confirm these findings and those studies should include other variables such as the attitude toward.

(3) Socialization and friendship relations between elders and their families, friends and other significant persons should be encouraged. This can provide elders with social and emotional support that act as a significant buffer against psychosocial distress caused by retirement. In turn, this can enhance adjustment with retirement.

\section{CONFlicts of InTEREST Disclosure}

The authors declare that there are no competing interests.

\section{REFERENCES}

[1] Eliopoulos C. Gerontological Nursing (7th ed.). Philadelphia: Lippincott Williams \& Wilkins Company. 2010: 235-47.
[2] Miller CA. Nursing for Wellness in Older Adult (5th ed.). Philadelphia: Lippincott Williams and Wilkins Company. 2009: 447-53.

[3] MacBean EC. Retirement Realities: Retirement Just Aren't What It 
Used to Be. Journal of Financial Service Professionals. 2007: 40-50.

[4] Ross DG, Wills L. Measuring financial preparation for retirement: a new scale using Australian evidence. Financial Services Review. 2009; 18: 381-99.

[5] Ministry of Solidarity and Social Justice, Central Department for Social Welfare, General Department for Family and Childhood Seniors' Division. Available from: http: //www . ohchr . org. Retrieved on: September 25/2014

[6] Ebersole P, Hess P, Touhy T, et al. Gerontological Nursing and Healthy Aging (2nd ed.). USA: Mosby Company; 2007. p. 118-23.

[7] Atchley RC. Activity adaptations to the development of functional limitations and results for subjective well-being in later adulthood. Journal of Aging Studies. 1998; 12: 19-38. http://dx.doi .org/1 $0.1016 / \mathrm{S} 0890-4065$ (98) 90018-4

[8] Reed J, Clarke CL, Macfarlane A. Nursing Older Adults. UK: McGraw-Hill Company; 1998. p. 260-70.

[9] Linton AD, Lach HW. Matteson \& McConnell's Gerontological Nursing: Concepts and Practice ( 3 rd ed.) USA: Elsevier Company; 2007. p. $640-42$.

[10] Stephan Y. Openness to experience and active older adult's life satisfaction: A trait 224 and facet-level analysis. Personality and Individual Differences. 2009; 47: 637-41. http://dx. doi .org/10.1016 /j.paid.2009.05.025

[11] Sarason IG, Sarason BR. Abnormal psychology: The problem of maladaptive behavior. Englewood Cliffs: Prentice Hall; 1987.

[12] Szinovacz ME, De Viney S, Davey A. Influences of family obligations and relationships on retirement: Variation by gender, race, and marital status. Journal of Gerontology: Social Sciences. 2001; 56B(1): 20-S27.

[13] Wells Y, deVaus D, Kendig H, Quine S, Petralia W. Healthy retirement project: technical report (2006). [Electronic version]. Retrieved March 8, 2014. Available from: http://www. latrobe.edu.au/a lpc/projects/hrp.pdf

[14] Leung C, Earl K. Retirement Resources Inventory: Construction, factor structure and psychometric properties. Journal of Vocational Behavior. 2014; 81: 171-82.

[15] Moen P. Midcourse: Navigating retirement and a new life stage. In: J. T. Mortimer \& M. J. Shanahan (Eds.), Handbook of the life course. New York: Kluwer; 2003. p. 269-91.

[16] Wang M, Henkens K, van Solinge H. Retirement adjustment: A review of theoretical and empirical advancements. American Psychologist. 2011; 66: 204-13. PMid:21341882. http://dx.doi.o $\mathrm{rg} / 10.1037 / \mathrm{a} 0022414$

[17] Dave D, Rashad I, Spasojevic J. The effects of retirement on physical and mental outcomes. Southern Economic Journal. 2008; 75: 497-523.

[18] Wang M. Profiling retirees in the retirement transition and adjustment process: Examining the longitudinal change patterns of retirees' psychological well-being. Journal of Applied Psychology. 2007; 92: 455-4. PMid:17371091. http://dx.doi.org/10.1037/0021-9 010.92 .2 .455

[19] Kim JE, Moen P. Retirement transitions, gender and psychological well-being: a life-course ecological model. Journal of Gerontology: Psychological Science. 2002; 57B(3): 212-22.

[20] Quick HE, Moen P. Gender, employment and retirement quality: A life course approach to the differential experiences of men and women. Journal of Occupational Health Psychology. 1998; 3(1): 44-64. http://dx.doi.org/10.1037/1076-8998.3.1.44

[21] van Solinge H, Henkens K. Couple's adjustment to retirement: a multi-factor panel study. Journal of Gerontology: Social Sciences. 2005; 60(1): S11-S20. PMid:15643041. http://dx.doi.org/10. 1093/geronb/60.1.S11

Published by Sciedu Press
[22] Isaksson K, Johansson G. Adaptation to continued work and early retirement following downsizing: Long-term effects and gender differences. Journal of Occupational and Organizational Psychology. 2000; 73(2): 241-56.

[23] Smith DB, Moen P. Retirement satisfaction for retirees and their spouses: Do gender and the retirement decision-making process matter? Journal of Family Issues. 2004; 25(2): 262-85. http: //dx.doi.org/10.1177/0192513X03257366

[24] Hagedoorn M, Coyne JC, Sanderman R. Does marriage protect older people from distress? The role of equity and recency of bereavement. Psychology and Aging. 2006; 21(3): 611-20. PMid:16953722. http://dx.doi.org/10.1037/0882-7974.21.3.611

[25] Szinovacz ME, Davey A. Honeymoons and joint lunches. Effects of retirement and spouse's employment on depressive symptoms. Journal of Gerontology: Psychological Sciences. 2004; 59B(5): 233-45.

[26] Price KF, Joo F. Exploring the relationship between marital status and women's retirement satisfaction. International Journal of Aging and Human Development. 2005; 61: 37-55. http://dx. doi .org /10.2190/TXVY-HAEB-XOPW-OOQF

[27] Bierman A, Fazio EM, Milkie MA. A multifaceted approach to the mental health advantage of the married: Assessing how explanations vary by outcome measure and unmarried group. Journal of Family Issues. 2006; 27: 554-82. http://dx.doi .org/10.1177/01925 $13 \times 05284111$

[28] Forrest AD, Fraser RH, Priest RG. Environmental factors in depressive illness. British Journal of Psychiatry. 1981; 8: 243-53.

[29] Lachine OA. The effect of a nursing intervention program on the loneliness experienced by elderly people. Unpublished thesis, Doctor Degree, Alexandria: University of Alexandria, Faculty of Nursing; 1998.

[30] Lusardi A, Mitchell OS. Baby Boomer retirement security: The roles of planning, financial literacy, and housing wealth. Journal of Monetary Economics. 2003; 54: 205-224.

[31] Asamoah N. Adjustment towards Retirement. 2012. Available from: http://ir.knust.edu.gh/bitstream/123456789/44 92/1/Nicholas\%20Asamoah. pdf. Retrieved on: July 15/2014.

[32] Maas ML, Buchwalter KC, Hardy MD, et al. Nursing care of older adults: diagnosis, outcomes and intervention. London: Mosby Company; 2001. p. 763-77.

[33] Kim JE, Moen P. Is retirement good or bad for subjective wellbeing? Current Directions in Psychological Science. 2001; 10: 83-86. http://dx.doi.org/10.1111/1467-8721.00121

[34] Windle G, Woods RT. Variations in subjective well being. The mediating role of a psychological resource. Ageing and Society. 2004; 24 : 583-604. http://dx.doi.org/10.1017/S0144686X04002107

[35] Taylor MA, Goldberg C, Shore LM, et al. The effects of retirement expectations and social support on post-retirement adjustment: A longitudinal analysis. Journal of Managerial Psychology. 2008; 23 : 458-70. http://dx.doi.org/10.1108/02683940810869051

[36] Vinick BH, Ekerdt DJ. Retirement: What happens to husband-wife relationships? Journal of Geriatric Psychiatry. 1991; 24: 23-40.

[37] Lockenhoff CE, Terracciano A, Costa PT. Five-factor model personality traits and the retirement transition: Longitudinal and crosssectional associations. Psychology and Aging. 2009; 24(3): 722-28. PMid:19739928. http://dx.doi.org/10.1037/a0015121

[38] Mayer JD, Salovey P. What is emotional intelligence? In P. Salovey, \& D. J. Sluyter (Eds.), Emotional development and emotional intelligence: Educational implications (pp. 3-34). New York: Basic Books. 1997.

[39] Slaski M, Cartwright S. Health, performance and emotional intelligence: An exploratory study of retail managers. Stress and Health. 2002; 18: 63-8. http://dx.doi.org/10.1002/smi.926 
[40] Slaski M, Cartwright S. Emotional intelligence training and its implications for stress health and performance. Stress and Health. 2003; 19: 233-39. http://dx.doi.org/10.1002/smi.979

[41] Strawbridge WJ, Wallhagen MI, Cohen RD. Successful aging and well-being: Self-rated compared with Rowe and Kahn. The Gerontologist. 2002; 6: 727-33. http://dx.doi.org/10.1093/geron t/42.6.727

[42] Fernández-Ballesteros R, Zamarrón MD, Rudinger G, et al. Assessing competence: The European survey on aging protocol (ESAP). Gerontology. 2004; 50: 330-47.

[43] Jones TG, Rapport LJ, Hanks RA, et al. Cognitive and psychological predictors of subjective well-being in urban older adults. The Clinical Neuropsychologist. 2003; 17: 3-18. PMid:12854007. http://dx.doi.org/10.1076/clin.17.1.3.15626

[44] Donaldson T, Earl JK, Muratore AM. Extending the integrated model of retirement adjustment: Incorporating mastery and retirement planning. Journal of Vocational Behaviour. 2010; 77: 279-89. http://dx.doi.org/10.1016/j.jvb.2010.03.003

[45] Price CA, Balaswamy S. Beyond health and wealth: Predictors of women's retirement satisfaction. International Journal of Aging and Human Development. 2009; 68: 195-214. http://dx.doi.org/1 $0.2190 / \mathrm{AG} .68 .3 . \mathrm{b}$

[46] Reitzes DC, Mutran EJ. The Transition to retirement: stages and factors That influence retirement adjustment. International Journal of Aging Human and Development. 2004; 59(1): 63-84. http: //dx . doi .org/10.2190/NYPP-RFFP-5RFK-8EB8

[47] van Solinge H, Henkens K. Adjustment to and satisfaction with retirement: Two of a kind? Psychology and Aging. 2008; 23(2): 422-34 PMid:18573015. http://dx.doi.org/10.1037/0882-7974.23 .2 .422

[48] Schmidt JA, Lee K. Voluntary retirement and organizational turnover intentions: The differential associations with work and non-work commitment constructs. Journal of Business Psychology. 2008; 22: 297-309. http://dx.doi.org/10.1007/s10869-008-9068-y
[49] Wong JY, Earl JK. Towards an integrated model of individual, psychosocial, and organizational predictors of retirement adjustment Journal of Vocational Behavior. 2009; 75: 1-13. http://dx.doi.o $\mathrm{rg} / 10.1016 / \mathrm{j} \cdot \mathrm{jvb} .2008 .12 .010$

[50] Douglas A, Hershey JC, Mowen JM. An experimental comparison of retirement planning intervention seminars. Educational gerontology. 2003; 29: 339-59. http://dx . doi .org/10.1080/713844333

[51] Clarke-Murphy M, Gerrans P. Consultation and resource usage in retirement savings decisions: Australian Evidence of Systematic Gender Differences. Financial Services Review. 2001; 10(1-4): 273-90. http://dx.doi.org/10.1016/S1057-0810(01)00086-5

[52] Elder HW, Rudolph PM. Beliefs and actions: Expectations and savings decisions by older Americans. Financial Services Review. 2000; 9: 33-45. http://dx.doi.org/10.1016/S1057-0810(00)000 54-8

[53] Fore D. Do we have a retirement savings crisis in America? (Research Dialogue). New York: TIAA-CREF Institute. 2003.

[54] Hershey DA, Mowen JC. Psychological determinants of financial preparedness for retirement. The Gerontologist. 2000; 40: 687-97. http://dx.doi.org/10.1093/geront/40.6.687

[55] Joo S, Pauwels VW. Factors affecting workers' retirement confidence: A gender perspective. Financial Counseling and Planning. 2002; 13(2): 1-10.

[56] Taylor MA, Doverspike D. Retirement planning and preparation. In A. Adams \& Beehr, T. A. (Eds), Retirement: reasons, Processes, and Results (pp.53-82). New York, NY: Spring Publishing Company. 2003.

[57] Matour S, Prout MF. Psychological implications of retirement in the 21st century. Journal of Financial Service Professionals. 2007; 61(1): 57-63.

[58] Noone JH. Stephens Alpass CFM. Preretirement planning and wellbeing in later life: A prospective study research on aging. 2009; 31(3): 295-317. 